\title{
Plans and Living Practices for the Green Campus of Portland State University
}

\author{
Yoon Jung Choi ${ }^{1}$, Minjung $\mathrm{Oh}^{1}$, Jihye Kang ${ }^{2}$, Loren Lutzenhiser ${ }^{2}$ \\ ${ }^{1}$ Dept. of Housing \& Interior Design, Chungbuk Nat'l Univ. \\ Chungdae-ro 1, Seowon-Gu, Cheongju, Chungbuk, 28644, Korea. \\ ychoi@cbnu.ac.kr; minjo2014@naver.com \\ ${ }^{2}$ School of Urban Studies and Planning, Portland State Univ. U.S. \\ 506 SW Mill Street - Urban Center, Portland, OR 97201, U.S.A. \\ jhk0126@gmail.com; llutz@pdx.edu
}

\begin{abstract}
This study aims to comprehend Portland State University (PSU)'s green campus strategies, and students' level of knowledge and living practices related to green campus. PSU's sustainable campus plan has been nationally and internationally recognized. A literature review, field investigation, and interviews were conducted to ascertain the PSU green campus strategies. This study also used a survey as a methodology to understand students' level of knowledge and practices. The survey results were analyzed by SPSS. Green campus projects at PSU were operated by official organizations and funded according to PSU's long term plans in 12 multilateral categories: administration, energy, water, climate action, green buildings, green purchasing, waste reduction and recycling, food and dining services, transportation, land use, action, and education and student activity. The survey results show that the level of students' understanding about PSU's green campus strategies was somewhat low, but the amount of practice of a sustainable lifestyle was higher. Students who had taken sustainable-related courses or were engaged in sustainable activities had more knowledge about green campus strategies than students who had not. Therefore, it would be important to focus more on educating students and developing related programs in order to have more positive effects of green campus projects.
\end{abstract}

Keywords: green campus, strategies, living practices for sustainability, Portland State University

\section{Introduction}

\subsection{Purpose}

A university campus is an entity that consumes a considerable amount of energy and the level of energy-saving living practices on campus remains lower than in housing environments, partly because the individuals' practices are not directly tied to economic incentives.

A university campus is a scaled-down form of an urban system. It has the elements of a city, with infrastructure such as roads, transportation, and electricity. It contains buildings and has systems that use energy and discharge waste products. Because of this, a university campus can serve as a testbed to analyze the effectiveness of green systems and green features that could be applied to future cities.

University students will be the decision-makers of society in the future. By then, they might be in a position of making policy decisions or developing facilities and products for the general public. Even if not, they need to be educated in order to have sufficient knowledge and a proper set of values to vote for competent representatives who will enact green initiatives. Since a university trains future decision-makers and often fosters environment-friendly education, it would be advisable to build green campuses where students can practice green living.

Consequently, it is essential to transform the currently energy-wasteful university campuses into green campuses, tackle the urgent issues of carbon dioxide emission and global warming, and enhance people's health and well-being.

There are two main aspects to building a green campus. The first concerns the physical environment to reduce energy consumption and the carbon footprint, which includes land use, green buildings, and green features. The second is the socio-cultural aspect that involves management, education, practice, and a relationship with the local community to effectively plan and use the physical elements of a green campus. 
In this study, we investigated the physical environment for a green campus by examining Portland State University (PSU), one of the leading examples of green campus initiatives. For the socio-cultural aspect, we surveyed the students' level of knowledge and living practices as related to a green campus. The analysis results will provide valuable information to assess the state of the green campus at PSU, provide foundations for the future direction of education on green campuses, and support green campus initiatives domestically and internationally.

\subsection{PSU: Finding a Research Subject}

PSU is located in Portland, Oregon, in the United States. Both the city of Portland and the state of Oregon are widely known for their environment-friendly policies and practices.

In 2014, PSU was ranked as one of the top 10 universities as an energy-conserving college in the Campus Conservation Nationals [1].Its president was appointed as chairman of the American College and University Presidents' Climate Commitment (ACUPCC). While many US universities are located in suburban areas, and form a university town, PSU is located in downtown Portland, Oregon's largest city, and it shares many overlapping features with typical university campuses in South Korea. Thus, PSU could serve as a useful benchmark for South Korean universities.

\section{Literature Review}

\subsection{Green Campus Policies in the United States}

The ACUPCC was organized in 2006 to build a college network that shares information about climate change and greenhouse gas emissions, provides a frame for universities to make their plan and practice that plan for climate neutrality [2]. The Advancement of Sustainability in Higher Education (AASHE) is a non-government organization engaged in educational activities. Specifically, it supports the generalization of sustainability in higher education and research on sustainability [3-4]. The U.S. Green Building Council (USGBC) introduced a green building certification program, LEED (Leadership in Energy \& Environmental Design), and it provides and assesses guidelines for green buildings. It also facilitates efforts to build green campuses through its Center for Green Schools [5]. The International Sustainable Campus Network (ISCN) facilitates network-building and cooperation among colleges and assists in the development of sustainable campuses in conjunction with the Global University Leadership Forum [6-7]. The United States Environmental Protection Agency (EPA) is a government-level organization that supports various activities to create a healthier living environment, from the enactment of law to research and environmental education [8-9].

\subsection{Previous Research}

Earlier studies can be grouped into studies on the environment of green campus and studies on users' knowledge and their understanding of the green campus.

The former includes the research of Taylor (2013), who introduced the case of Kingston University in the United Kingdom [10], and Cho (2011), who investigated five universities in Seoul to identify characteristics of a green campus, based on a site visit and interviews with university staff [11]. Kim et al. (2013) examined the green campus system in the United States using the case of Harvard University as an example and compared green campus system in the United States with South Korea by literature review [12]. Both studies of the South Korea focused on particular aspects of the green campus, rather than taking a comprehensive approach.

As for studies on knowledge and understanding of the green campus, the survey was the most commonly used method. Speake, Edmondson, and Nawaz (2013) studied Liverpool Hope University students to determine their understanding of green space, frequency of use, level of satisfaction, and how to improve green space [13]. Kim (2010) surveyed college students for their knowledge of the green campus and environment, their perception of environmental preservation, and related actions [14]. These two studies suggest the need to promote and strengthen education on green campuses.

\section{Methods}

\subsection{Literature Review and Internet Survey}

We reviewed the reports related to campus sustainability published by PSU and postings on its website. 


\subsection{Interviews}

We conducted interviews with university staff to obtain additional information about PSU's green campus initiatives (Table 1).

\subsection{Field Investigation}

To identify the physical environmental elements of PSU's green campus, we visited the campus and took photographs. We examined all the green features and the condition of LEED-certified buildings on campus. We also interviewed the users of related staff during field investigation (Table 1).

Table 1: Interview outline.

\begin{tabular}{|c|c|c|c|}
\hline & Time & Interviewee & Contents \\
\hline \multirow{3}{*}{$\begin{array}{l}\text { Interview } \\
\text { with staff }\end{array}$} & $\begin{array}{c}11 / 05 / 201 \\
4\end{array}$ & A campus sustainability manager at $\mathrm{CSO}$ & $\begin{array}{l}\text { PSU's plans and goals for green } \\
\text { campus }\end{array}$ \\
\hline & \multirow{2}{*}{$\begin{array}{c}11 / 24 / 201 \\
4\end{array}$} & A sustainability curriculum coordinator at ISS & \multirow[b]{2}{*}{ PSU's sustainable educational program } \\
\hline & & $\begin{array}{l}\text { A sustainability leadership and outreach } \\
\text { coordinator at SLC }\end{array}$ & \\
\hline \multirow{3}{*}{$\begin{array}{c}\text { Interview } \\
\text { during field } \\
\text { investigatio } \\
\mathrm{n}\end{array}$} & $\begin{array}{l}09 / 15 / 201 \\
4\end{array}$ & $\begin{array}{l}\text { Two residents of Broadway Housing (green } \\
\text { building) }\end{array}$ & $\begin{array}{l}\text { Sustainable practices and knowledge } \\
\text { about a green building }\end{array}$ \\
\hline & $\begin{array}{l}02 / 09 / 201 \\
5\end{array}$ & Sustainability tour staff & $\begin{array}{l}\text { Features or facilities of PSU green } \\
\text { campus }\end{array}$ \\
\hline & $\begin{array}{l}02 / 17 / 201 \\
5\end{array}$ & $\begin{array}{l}\text { A campus sustainability manager and a } \\
\text { management staff at CSO }\end{array}$ & $\begin{array}{l}\text { Eco roofs of Cramer Hall and } \\
\text { Broadway Housing }\end{array}$ \\
\hline
\end{tabular}

\subsection{Survey}

We conducted a survey during February 5-13, 2015 to examine students' knowledge of PSU's sustainability plans and their living practices.

The survey was designed as shown in Table 2. It was modified and revised based on consultation with the SRL (Survey Research Lab) and a preliminary survey was conducted to test the level of understanding of the survey. After completing the survey design, we applied for exemption, obtained an approval from the IRB (Institutional Review Board), and launched our survey.

The respondents were PSU's undergraduate students. We selected 5 relatively large classes and mentoring sections that were composed of various students in terms of gender, grade, and majors. We then visited the classes to distribute the surveys and collect the responses after receiving permission from the instructors. A total 264 copies of the survey were distributed, of which 216 were collected and 209 were used for analysis.

The analysis method was a statistical analysis with simple frequencies and percentages, cross-tabbing, t-testing, and ANOVA.

Table 2: Survey Questions.

\begin{tabular}{|c|l|}
\hline Categories & \multicolumn{1}{c|}{ Items } \\
\hline $\begin{array}{c}\text { Respondent } \\
\text { information }\end{array}$ & $\begin{array}{l}\text { Gender, study period at PSU, living on campus, previous experience of living on campus, } \\
\text { experience of taking sustainability related course, experience of enrolling student activity } \\
\text { focused on sustainability }\end{array}$ \\
\hline $\begin{array}{c}\text { Knowledge about } \\
\text { a green campus }\end{array}$ & $\begin{array}{l}\text { Total of 41 items for features or programs of PSU green campus; offered to check the items if } \\
\text { they felt they could explain to a friend }\end{array}$ \\
\hline $\begin{array}{c}\text { Living practices } \\
\text { for sustainability }\end{array}$ & $\begin{array}{l}\text { Total of 18 questions about PSU's recommendations for sustainable living; four-point scale from } \\
\text { "never(1)" to "often(4)" with the additional category of "not applicable" }\end{array}$ \\
\hline
\end{tabular}




\section{Plans for the Green Campus}

Green campus projects in PSU are operated by official organizations and funded through the long term plans of PSU in 12 multilateral categories: administration, energy, water, climate action, green buildings, green purchasing, waste reduction and recycling, food and dining services, transportation, land use, action, and education and student activity. Distinctive sustainable plans or features were in Table 3.

Table 3: Categories of PSU Green Campus Plans.

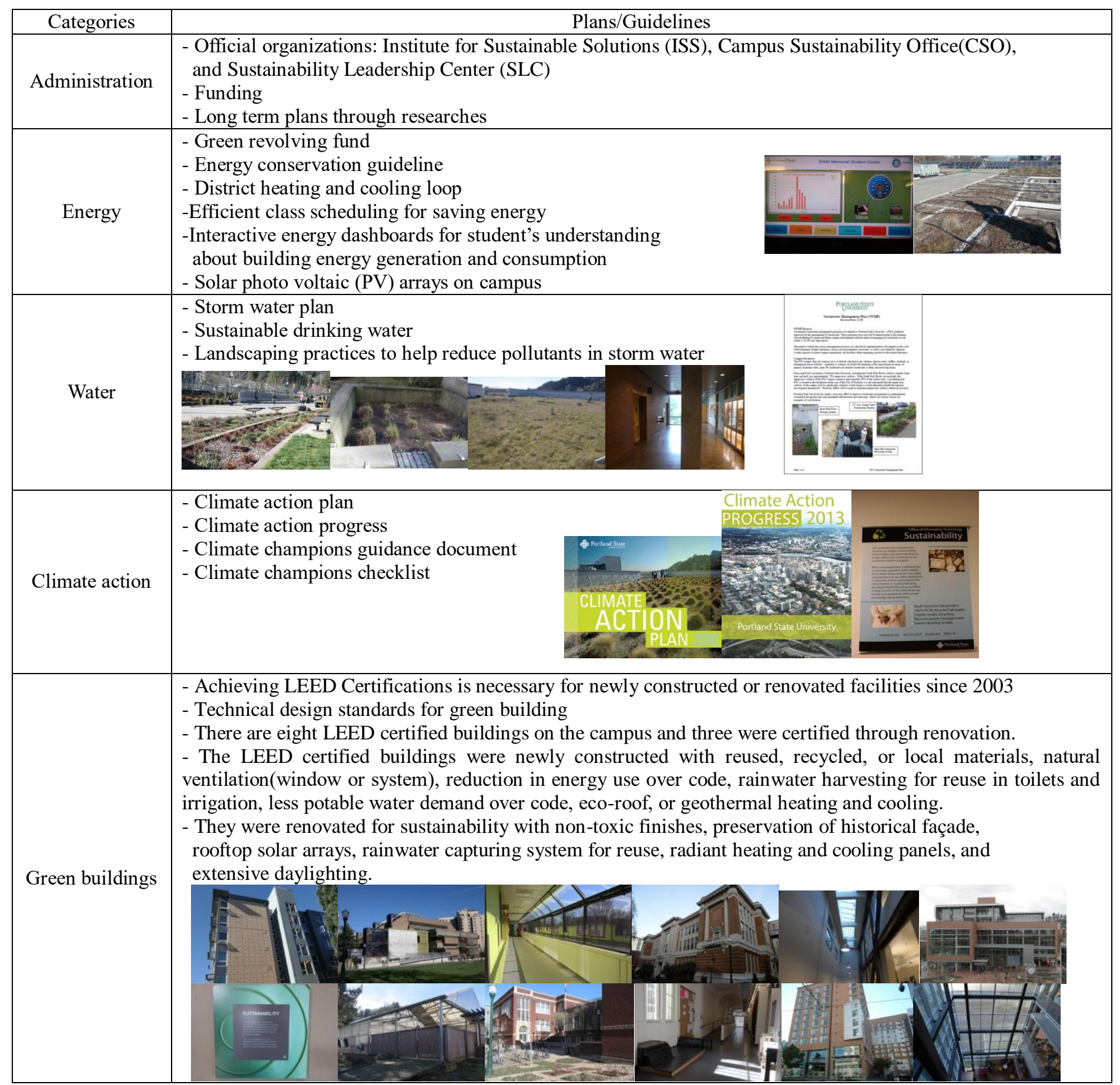




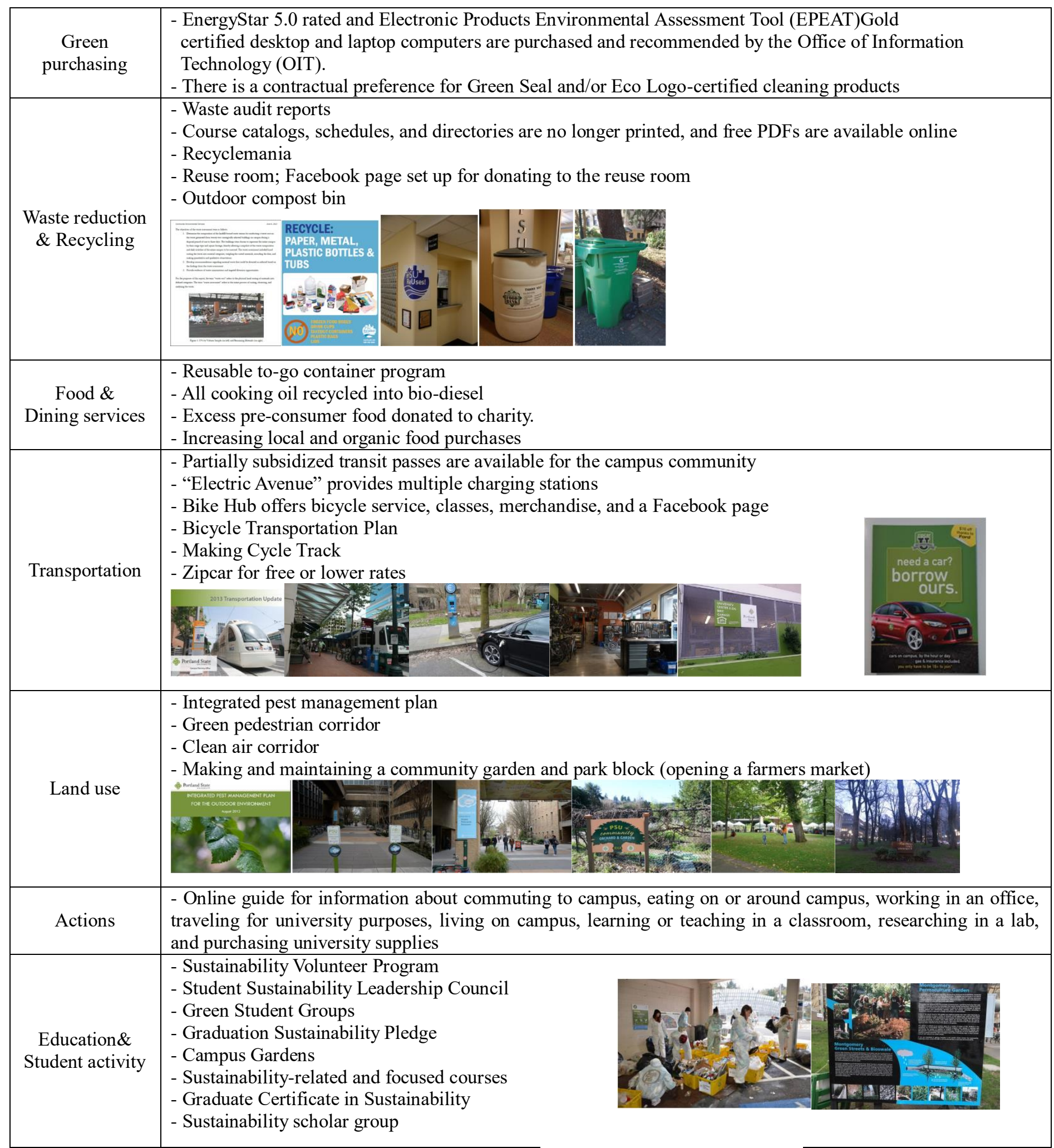

Sources: http://www.pdx.edu/planning-sustainability/greencampus, field investigation, and interviews 


\section{Living Practices}

\subsection{Respondents}

The number of male and female respondents was similar. The study period of "less than 1 year" (33\%) was the most frequent response followed by " $1 \sim$ Less than 2 years" $(27.3 \%)$. The percentage of students who were living on campus (29.2\%), took sustainability related course (15.3\%), or enrolled in activities focused on sustainability (4.8\%) was low.

\subsection{Knowledge and Living Practices}

The survey results show that the level of the students' understanding about green campus strategies was somewhat low (Table 4), but the amount of sustainable practice was higher (response average for each question: 1.79 3.62, total average: 2.85 at four-point scale from "never(1)" to "often(4)").

Students who previously took courses related to sustainability or were engaged in sustainable student activities were more knowledgeable about PSU green campus strategies and plans than those students who had not (Table 5). Therefore, it would be important to focus more on educating students and develop related programs in order to have more positive effects for green campus projects.

Table 4: Students' understanding about Green Campus Plans/Features.

\begin{tabular}{|c|c|c|c|}
\hline \multicolumn{2}{|r|}{ Survey Questions } & $\mathrm{f}$ & $\% *$ \\
\hline \multirow{3}{*}{ Energy } & Solar photovoltaic (PV) & 23 & 11.0 \\
\hline & LED fixtures at parking garages & 30 & 14.4 \\
\hline & Lights off reminder stickers on switches & 60 & 28.7 \\
\hline \multirow{6}{*}{ Water } & Rainwater harvesting (at Epler Hall, ASRC) & 36 & 17.2 \\
\hline & Pervious pavers & 6 & 2.9 \\
\hline & Water efficient fixtures(in restrooms) & 44 & 21.1 \\
\hline & Storm water planters & 20 & 9.6 \\
\hline & Bioswales (at Helen Gordon, Epler Hall) & 15 & 7.2 \\
\hline & Green(Eco) roofs & 48 & 23.0 \\
\hline \multirow{5}{*}{ Green buildings } & LEED Certified building & 56 & 26.8 \\
\hline & Low-emitting materials & 20 & 9.6 \\
\hline & Occupancy sensor control for lighting & 38 & 18.2 \\
\hline & Ventilation system for IAQ & 0 & 0 \\
\hline & Radiant heating and cooling panels & 21 & 10.0 \\
\hline \multirow{10}{*}{$\begin{array}{c}\text { Waste } \\
\text { reduction \& } \\
\text { Recycling }\end{array}$} & Recyclemania & 9 & 4.3 \\
\hline & Mug runners program & 5 & 2.4 \\
\hline & Chuck it for charity program & 11 & 5.3 \\
\hline & Lending library (on online) & 27 & 12.9 \\
\hline & Reusable to-go containers program & 38 & 18.2 \\
\hline & Work order center for special request materials(on online) & 8 & 3.8 \\
\hline & Reuse room (in Cramer Hall) & 88 & 42.1 \\
\hline & Pop-up-swaps & 4 & 1.9 \\
\hline & Surplus property program & 3 & 1.4 \\
\hline & Outdoor compost bin & 49 & 23.4 \\
\hline
\end{tabular}




\begin{tabular}{|c|c|c|c|}
\hline \multirow{7}{*}{ Transportation } & Transit passes through campus & 128 & 61.2 \\
\hline & Bike hub & 116 & 55.5 \\
\hline & Bike land (on Broadway) & 96 & 45.9 \\
\hline & Bike to PSU Challenge \& Bike Commute Challenge & 27 & 12.9 \\
\hline & Electric avenue & 93 & 44.5 \\
\hline & VikeBikes program & 13 & 6.2 \\
\hline & Zipcar for free or lower rates program & 66 & 31.6 \\
\hline \multirow[b]{2}{*}{ Land use } & Green pedestrian corridor (in Montgomery Street) & 34 & 16.3 \\
\hline & $\begin{array}{l}\text { Clean air corridor } \\
\text { (from the end of Lincoln Hall to the end of Shattuck Hall) }\end{array}$ & 99 & 47.4 \\
\hline \multirow{8}{*}{$\begin{array}{c}\text { Education\& } \\
\text { Student activity }\end{array}$} & Living Lab Initiative & 6 & 2.9 \\
\hline & Sustainability volunteer program & 9 & 4.3 \\
\hline & Green student groups & 11 & 5.3 \\
\hline & Campus gardens & 50 & 23.9 \\
\hline & EcoReps program & 9 & 4.3 \\
\hline & Student Sustainability Leadership Council & 7 & 3.3 \\
\hline & Sustainability scholar group & 0 & 0 \\
\hline & Sustainability-related and focused courses & 15 & 7.2 \\
\hline & Average** & 35.1 & 16.8 \\
\hline
\end{tabular}

* The percentage shows the portion or the respondents who checked to each questions among the whole 209 repondents

** Average is the total average or the number of respondents who checked to each questions

Table 5: Differences of knowledge by respondents' backgrounds.

\begin{tabular}{|c|c|c|c|c|}
\hline \multicolumn{2}{|l|}{ Items } & frequenc & Average & t-value \\
\hline \multirow{2}{*}{ Gender } & Male & 105 & 6.63 & \multirow{2}{*}{$-.642^{\mathrm{n} . \mathrm{s}}$} \\
\hline & Female & 100 & 7.12 & \\
\hline \multirow{2}{*}{ Living on campus } & Yes & 61 & 7.38 & \multirow{2}{*}{$.621^{\text {n.s. }}$} \\
\hline & No & 148 & 6.83 & \\
\hline \multirow{2}{*}{ Previous experience of living on campus } & Yes & 28 & 9.79 & \multirow{2}{*}{$3.111^{\text {** }}$} \\
\hline & No & 118 & 6.19 & \\
\hline \multirow{2}{*}{$\begin{array}{l}\text { Experience of taking course } \\
\text { on sustainability }\end{array}$} & Yes & 32 & 10.50 & \multirow{2}{*}{$2.751^{* *}$} \\
\hline & No & 176 & 6.33 & \\
\hline \multirow{2}{*}{$\begin{array}{c}\text { Experience of enrolling student activity focused on } \\
\text { sustainability }\end{array}$} & Yes & 10 & 11.60 & \multirow{2}{*}{$2.632^{* *}$} \\
\hline & No & 198 & 6.74 & \\
\hline
\end{tabular}

n.s. $:$ not significant $* \mathrm{p}<.05 * * \mathrm{p}<.01 * * * \mathrm{p}<.001$

\section{Conclusions}

In acknowledging the gravity of climate change issues, PSU has made diversified efforts to reduce carbon dioxide emissions and waste disposal. The university formed an official committee dedicated to making a green campus, with designated staffs for budgeting and research. Based on research, they establish a long-term plan to address the issue from 
multiple perspectives. Green campus projects in PSU were operated by official organizations, funding, with long term plans of PSU in multilateral 12 categories. Those were administration, energy, water, climate action, green buildings, green purchasing, waste reduction \& recycling, food \& dining services, transportation, land use, action, and education \& student activity. Distinctive sustainable plans or features were district heating and cooling loop, storm water plan, climate action plan \& progress, achieving LEED Certifications for newly constructed or renovated facilities, waste audit reports, public transportation in campus, "Electric Avenue" providing multiple charging stations for electric cars, "Park Block," as well as large numbers of sustainability-related courses and student groups. They are set apart from green campus initiatives in Korea in that it has a dedicated organization, budget and research resources that enable long-term planning and implementation of diversified efforts.

Efforts to establish a physical environment for a green campus can be used as educational materials that students learn about in classes. They are also used in various areas, ranging from student activities, to leadership programs, and community programs, for greater participation in green campus initiatives and related education.

The survey results show that the level of students' understanding about green campus strategies was somewhat low, but the amount of practice about sustainable lifestyle was higher. Students who previously took sustainable related courses or were engaged in sustainable activities had more knowledge about PSU green campus strategies and plans than students who were not. Therefore, it would be important to focus more on educating students and develop related programs in order to have more positive effects of green campus projects.

The findings of this study, strategies of PSU green campus project and necessity of educating current students, would help other universities initiating green campus projects to create and develop related programs.

\section{Acknowledgements}

This research was supported by Basic Science Research Program through National Research foundation of Korea(NRF) funded by the Ministry of Education (2015R1D1A3A01019328)

\section{References}

[1] (2015, May 10). Green Rankings [Online]. Available: http://www.pdx.edu/sustainability/green-rankings.

[2] ACUPCC. (2015, May 13). American College \& University Presidents' Climate Commitment [Online]. Available: http://www2.presidentsclimatecommitment.org/html/commitment.pdf.

[3] AASHE. (2015, May 13). About AASHE [Online]. Available: http://www.aashe.org.about.

[4] AASHE. (2015, May 13). 2014 Annual Report [Online]. Available: http://www.aashe.org/files/aashe_annual_report_2014.pdf.

[5] (2015, May 13). The Center for green schools [Online]. Available: http://www.centerforgreenschools.org/.

[6] ISCN. (2015, May 13). International Sustainable Campus Network [Online]. Available: http://www.internationalsustainable-campus-network.org/.

[7] ISCN. (2015, May 13). Purpose. [Online]. Available: http://www.international-sustainable-campusnetwork.org/about/purpose.

[8] United States Environmental Protection Agency. (2015, May 13). EPA History [Online]. Available: http://www2.epa.gov/aboutepa/epa-history.

[9] EPA. (2015, May 13). Our Mission and What We Do. [Online]. Available: http://www2.epa.gov/aboutepa/ourmission-and-what-we-do.

[10] Ros Taylor, "Bottoms up for sustainability - The Kingston experience," in The Sustainable University: Progress and prospects, Ed. New York: Routledge, 2013, pp. 256-280.

[11] K-C. Cho, "A Study on comparative analysis of Characteristic for Sustainable University Campuses (Analysis on the Green Campus)," Ph.D. dissertation, Dept. Urban Engineering., Graduate School of The University of Seoul, Seoul, Korea.

[12] D-H. Kim, H. J. Lee, K-E. Kim, and S-Y. Kim, "A Case Study on the Green Campus Operating System-Focused on the Green Campus Support Institutions of the United States and Harvard University," Journal of the Korean Institute of Educational Facilities, vol. 95, pp. 11-22., 2013.

[13] J. Speake, S. Edmondson, and H. Hawaz, "Everyday encounters with nature: Students' perceptions and use of university campus green spaces," Journal of Studies and Research in Human Geography., vol. 7, no. 1, pp. 21-31, 2013. 
[14] S-Y. Kim, "A Study on the Environmental Consciousness and Behaviors of University Students for construct EcoCampus," Master. dissertation, Dept. Urban Administration., Graduate School of The University of Seoul, Seoul, Korea. 